\title{
Chemical profile and larvicidal activity of essential oil obtained from the leaves of
}

\section{Plectranthus amboinicus (Lour.) Spreng}

\author{
Perfill químico e atividade larvicida de óleo essencial obtido a partir das follhas de Plectranthus \\ amboinicus (Lour.) Spreng \\ Perfil químico y actividad larvicidal del aceite esencial obtenido de las hojas de Plectranthus \\ amboinicus (Lour.) Spreng
}

Received: 03/12/2021 | Reviewed: 03/19/2021 | Accept: 03/26/2021 | Published: 04/04/2021

Ana Patrícia Matos Pereira

ORCID: https://orcid.org/0000-0003-4478-4209

Universidade Federal do Maranhão, Brasil

E-mail: ap.matos11@hotmail.com

Thércia Gabrielle Teixeira Martins

ORCID: https://orcid.org/0000-0002-0506-1748

Universidade Federal do Maranhão, Brasil

E-mail: thercia.martins@hotmail.com

Mariana Oliveira Arruda

ORCID: https://orcid.org/0000-0001-7097-7843

Faculdade Uninassau, Brasil

E-mail: mariana_o.arruda@yahoo.com.br

Andressa Almeida Santana Dias

ORCID: https://orcid.org/0000-0002-1671-8338 Faculdade Uninassau, Brasil

E-mail: andressasantana@gmail.com

Laiane Araújo da Silva Souto

ORCID: https://orcid.org/0000-0003-1782-5896 Faculdade Uninassau, Brasil

E-mail: laianesouto@gmail.com

Ari Pereira de Araújo Neto

ORCID: https://orcid.org/0000-0001-6903-4127

Universidade Federal do Delta do Parnaíba, Brasil

E-mail: aripereiraneto@gmail.com

Liane Batista da Cruz Soares

ORCID: https://orcid.org/0000-0001-9548-3911

Universidade Federal do Maranhão, Brasil

E-mail: lianebatistadacruz@hotmail.com

Ana Maria Almeida Silva Carvalho

ORCID: https://orcid.org/0000-0002-2075-5780

Universidade Federal do Maranhão, Brasil

E-mail: aninha_biomed@yahoo.com.br

Ricardo Teixeira de Sousa

ORCID: https://orcid.org/0000-0001-9304-507X LabMed e BioSaude, Brasil

E-mail: ric.teix.sousa@gmail.com

Carlos Eduardo Pereira Conceição ORCID: https://orcid.org/0000-0002-6735-9291 Hospital Guarás, Brasil

E-mail: dudaecarol21@gmail.com

Francilidia Oliveira Vitorino de Assunção Conceição ORCID: https://orcid.org/0000-0002-0079-7502

Universidade Federal do Maranhão, Brasil

E-mail: francilidiaassuncao@gmail.com

Gustavo Oliveira Everton

ORCID: https://orcid.org/0000-0002-0457-914X

Universidade Federal do Maranhão, Brasil

E-mail: gustavooliveiraeverton@gmail.com 


\begin{abstract}
This study aimed to determine the chemical constituents and larvicidal activity of the essential oil of Plectranthus amboinicus (Lour.) Spreng against larvae of the Aedes aegypti mosquito. The essential oil (EO) was extracted by hydrodistillation at $100^{\circ} \mathrm{C}$ for 3 hours. The chemical composition was obtained by Gas Chromatography coupled to Mass Spectrometry (GC / MS). To assess larvicidal activity, Aedes aegypti larvae were subjected to EO solutions in concentrations of $10-100 \mathrm{mg} \mathrm{L}^{-1}$, where larval mortality was assessed and the $\mathrm{LC}_{50}$ was determined using the Probit method. The main chemical constituent found in the EO was carvacrol, which is considered to be very promising for pharmaceutical synthesis. The EO showed larvicidal activity with an $\mathrm{LC}_{50}$ of $28.52 \mathrm{mg} \mathrm{L}^{-1}$. According to the results found, it was possible to evaluate that the analyzed EO is composed of substances that have an efficient larvicidal effect against Aedes aegypti, thus encouraging its potential for application.
\end{abstract}

Keywords: Essential oils; Larvicide; Chemical constituents.

\title{
Resumo
}

Este estudo teve por objetivo determinar os constituintes químicos e atividade larvicida do óleo essencial de Plectranthus amboinicus (Lour.) Spreng frente a larvas do mosquito Aedes aegypti. O óleo essencial (OE) foi extraído por hidrodestilação a $100{ }^{\circ} \mathrm{C}$ por $3 \mathrm{~h}$. A composição química foi obtida por Cromatografia Gasosa acoplada à Espectrometria de Massas (GC/MS). Para avaliação da atividade larvicida submeteu-se larvas de Aedes aegypti a soluções do $\mathrm{OE}$ em concentrações de $10-100 \mathrm{mg} \mathrm{L}^{-1}$, onde avaliou-se a mortalidade das larvas e determinou-se a $\mathrm{LC}_{50}$ a partir do método de Probit. O principal constituinte químico encontrado no EO foi o carvacrol sendo considerado grande promissor para síntese farmacêutica. O OE apresentou atividade larvicida com $\mathrm{LC}_{50}$ de $28,52 \mathrm{mg} \mathrm{\textrm {L } ^ { - 1 }}$. De acordo com os resultados encontrados, foi possível avaliar que o OE analisado é composto por substâncias que possuem um eficiente efeito larvicida frente ao Aedes aegypti, incentivado assim seu potencial de aplicação.

Palavras-chave: Óleos essenciais; Larvicida; Constituintes químicos.

\section{Resumen}

Este estudio tenía como objetivo determinar los componentes químicos y la actividad larvicidal del aceite esencial de Plectranthus amboinicus (Lour.) Spreng. Estordo frente a las larvas del mosquito Aedes aegypti. El aceite esencial (AE) fue extraído por hidrodistilación a $100^{\circ} \mathrm{C}$ durante $3 \mathrm{~h}$. La composición química fue obtenida por cromatografía de gases acoplada a espectrometría de masas (CG/EM). Para evaluar la actividad larvicidal, las larvas de Aedes aegypti se sometieron a soluciones de AE a concentraciones de 10-100 mg de $\mathrm{L}^{-1}$, donde se evaluó la mortalidad por larvas y se determinó $\mathrm{CL}_{50}$ a partir del método Probit. El principal componente químico encontrado en $\mathrm{AE}$ fue carvacrol siendo considerado un muy prometedor para la síntesis farmacéutica. El AE mostró actividad larvicidal con $\mathrm{CL}_{50}$ de 28,52 $\mathrm{mg} \mathrm{L}^{-1}$. Según los resultados encontrados, fue posible evaluar que el AE analizado está compuesto por sustancias que tienen un efecto larvicidal eficiente contra Aedes aegypti, fomentando así su potencial de aplicación.

Palabras clave: Aceite esencial; Larvicidal; Compuestos químicos.

\section{Introduction}

Plants are considered one of the main natural resources for medicinal use, due to their biological potential, whether due to the action of deadly diseases or diseases that affect living beings, therefore, according to the World Health Organization, almost $80 \%$ of the population in developing countries development uses them directly or indirectly for their basic health needs, either because of cultural tradition or because there are no other options, due to the high cost of traditional medicines for this population (Bermúdez,Oliveira-Miranda \& Velázquez, 2005; Alitonou et al., 2012; de Souza et al., 2020 ).

Multidisciplinary efforts have also led to an increase in the number of researches to obtain greater knowledge about a medicinal plant (de Souza et al., 2020). The study of substances extracted from plants has been shown to be indispensable over time, whether due to the great biological diversity in Brazil or the potential of this extraction. Thus, essential oils represent a viable alternative in several studies involving substances of plant origin (Gomes et al., 2019; Minott \& Brown, 2007).

Specific analyzes are necessary around the validation process, which includes chemical composition, proof of pharmacological, molluscicidal, microbial activity and possible toxicity in humans parameters that ensure the quality of raw materials of plant origin (Gomes et al., 2019).

The toxic potential of essential oils (EOs) and their compounds can vary significantly according to intrinsic and extrinsic factors (Kim et al., 2016). The chemical composition of EOs contributes significantly to the determination of the pharmacological potential attributed to plant species. In the case of EOs, it is recommended to regularly use the gas 
chromatography system coupled to the mass spectrum (GC / MS), in order to identify substances derived from secondary metabolism. EO extracted from medicinal plants have been widely used successfully in research aimed at epidemiological control (Mirzahosseini et al., 2017).

According to the Ministry of Health (2019), it was declared that in 2019, until the 12th Epidemiological Week (12/30/2018 to $03 / 23 / 2019$ ), there were 273,193 probable cases of dengue in the country, which had a growth of approximately $382 \%$ compared to the same period in 2018 (71.525 thousand).

In the last decades, it is noted that the diseases transmitted by the Aedes aegypti mosquito, specifically dengue, have grown exponentially worldwide. There are approximately 390 million dengue infections per year, including 96 million with clinical manifestations (Brahtt et al., 2013).

Among the methods used to control the larvae, the use of temephos organophosphate insecticide is the main measure adopted by the National Dengue Prevention Program in Brazil and by the World Health Organization (Carvalho et al., 2004; Crivelenti et al ., 2011; Prophiro et al., 2011).

In view of the importance of EOs and their wide application, the present study aims to determine the chemical constituents and the larvicidal potential of the essential oil of Plectranthus amboinicus (Lour.) Spreng against the larvae of Aedes aegypti, aiming at a safe, ecologically viable and efficient alternative fighting and controlling the population of Aedes aegypti in the country.

\section{Methodology}

\subsection{Obtaining plant material}

Leaves of Plectranthus amboinicus (Lour.) Spreng (thick-leaf mint) in the city of Palmeirândia (MA), being transported to the Laboratory of Research and Application of Essential Oils of the Federal University of Maranhão (LOEPAV / UFMA), where they were dried, crushed and stored for later analysis.

\subsection{Phytochemical screening}

A hydroalcoholic extract of the plant material obtained was prepared and it was subjected to chemical tests based on the methodology presented by Matos (2009). The tests performed to identify alkaloids, steroids, phenolics, flavonoids, glycosides, cardiac glycosides, saponins and tannins are described below:

\subsubsection{Steroids (Salkowsk test)}

About $100 \mathrm{mg}$ of dry extract was dissolved in $2 \mathrm{ml}$ of chloroform. Sulfuric acid was carefully added to form a lower layer. A reddish-brown color at the interface indicated the presence of a steroid ring.

\subsubsection{Alkaloids (Mayer's test)}

$1.36 \mathrm{mg}$ of mercury chloride were dissolved in $60 \mathrm{ml}$ and $5 \mathrm{mg}$ of potassium iodide dissolved in $10 \mathrm{ml}$ of distilled water, respectively. These two solvents were mixed and diluted to $100 \mathrm{ml}$ using distilled water. To $1 \mathrm{ml}$ of the aqueous acidic solution of the samples, a few drops of the reagent previously prepared were added. The formation ofwhite or pale precipitation showed the presence of alkaloids.

\subsubsection{Flavonoids}

In a test tube containing $0.5 \mathrm{~mL}$ of alcoholic extract from the samples, 5 to 10 drops of diluted $\mathrm{HCl}$ were added and a small amount of $\mathrm{Zn}$ or $\mathrm{Mg}$ was added to the solution, which was then boiled for a few minutes. The appearance of a reddish 
pink or dark brown color indicated the presence of flavonoids.

\subsubsection{Glycosides}

One small amount of alcoholic extract from samples was dissolved in $1 \mathrm{ml}$ of water and then aqueous sodium hydroxide was added. The formation of a yellow color indicated the presence of glycids.

\subsubsection{Cardiac glycosides}

About 100mg of extract was dissolved in $1 \mathrm{ml}$ of glacial acetic acid containing a drop of ferric chloride solution and $1 \mathrm{ml}$ of concentrated sulfuric acid was added. A brown ring obtained at the interface indicated the presence of an oxy sugar characteristic of cardenolides.

\subsubsection{Saponins}

A drop of sodium bicarbonate was added to a test tube containing about $50 \mathrm{ml}$ of an aqueous extract from the sample. The mixture was shaken vigorously and held for 3 minutes. A honey comb like foam was formed and showed the presence of saponins.

\subsubsection{Phenols}

For $1 \mathrm{~mL}$ of alcoholic sample solution, $2 \mathrm{~mL}$ of distilled water was added followed by a few drops of $10 \%$ aqueous ferric chloride solution. The formation of a blue or green color indicated the presence of phenols.

\subsubsection{Tannins}

In a test tube containing about $5 \mathrm{ml}$ of an aqueous extract, a few drops of $1 \%$ lead acetate solution were added. The formation of a yellow or red precipitate indicated the presence of tannins.

\subsection{Obtaining essential oils}

For the extraction of essential oils, the hydrodistillation technique was used with a Clevenger glass extractor coupled to a round bottom flask wrapped in an electric blanket as a heat generating source. $200 \mathrm{~g}$ of $P$. amboinicus leaves were used, adding distilled water (1:10). Hydrodistillation was carried out at $100^{\circ} \mathrm{C}$ for 3 hours, collecting the extracted essential oil. Each essential oil was dried by percolation with anhydrous sodium sulfate ( $\mathrm{Na} 2 \mathrm{SO} 4)$ and stored in a refrigerator until further analysis.

\subsection{Chemical constituents}

The EO constituents were identified by gas chromatography coupled to mass spectrometry (GC-MS). The conditions of analysis were as follows: Method: Adams. M; Injected volume: $0.3 \mu \mathrm{L}$; Column: Capillary HP-5MS (5\% diphenyl, $95 \%$ dimethyl polysiloxane) (Equivalent DB-5MS or CP-Sil 8CB LB / MS), in dimensions (30 mx $0.25 \mathrm{~mm}$ x $0.25 \mu \mathrm{m}$ ); Drag gas: He (99,9995); $1.0 \mathrm{~mL} / \mathrm{min}$; Injector: $280 \mathrm{oC}$, Split mode (1:10); Oven: $40 \mathrm{oC} \mathrm{(5.0} \mathrm{min.)} \mathrm{Up} \mathrm{to} 240 \mathrm{oC}$ at the rate of $4 \mathrm{oC}$.min

1, from $240 \mathrm{oC}$ to $300 \mathrm{oC}(7.5 \mathrm{~min})$ at the rate of $\left.8 \mathrm{oC} \cdot \mathrm{min}^{-1}\right)$; tT $=60.0 \mathrm{~min}$; Detector: EM1; EI (70 eV); Scan mode $(0.5 \mathrm{sec} /$ scan); Mass range: 40 - 500 daltons (one); Line transfer: $280 \mathrm{oC}$;; Filament: off 0.0 to $4.0 \mathrm{~min}$; Linear quadrupole mass spectrometer. The AMDIS (Automated Mass spectral Deconvolution Mass \& Identification System) program was used to identify the compounds in the sample. 


\subsection{Egg collection}

The eggs were collected at the Federal University of Maranhão, Campus Bacanga in São Luís / MA, using traps called ovitrampas. These consist of brown buckets $(500 \mathrm{~mL})$, made of polyethylene, with $1 \mathrm{~mL}$ of brewer's yeast and $300 \mathrm{~mL}$ of running water and two Eucatex straws are inserted for the mosquito's oviposition. The traps were inspected weekly for the replacement of straws and collection of eggs and sent to the Laboratory of Research and Application of Essential Oils (LOEPAV / UFMA) of the Technological Pavilion of the Federal University of Maranhão - UFMA.

Initially, the eggs of Aedes aegypti were placed to hatch at room temperature in a circular glass aquarium containing mineral water. The identification of the species followed the methodology proposed by Forattini (1962). The obtained larvae were fed with cat food according to the methodology of Silva et al., (1995) until they reached the third and fourth stages, the age at which the experiments were carried out.

\subsection{Larvicidal activity}

The tests for larvicidal activity were performed according to the adapted methodology proposed by Silva (2006). Initially, a stock solution of $100 \mathrm{mg} \mathrm{L}^{-1}$ of each of the EOs was prepared and diluted in a $2 \%$ DMSO solution. From this solution, five dilutions were prepared at concentrations 10,20,50,70 and $90 \mathrm{mg} \mathrm{L}^{-1}$. At each concentration, 10 larvae were added in the proportion $1 \mathrm{ml}$ per larva.

All tests were performed in triplicates and as a negative control, a solution formed of DMSO $2 \%$ was used, and as a positive control, a solution of temephos (O, O, O ', O'-tetramethyl O, O'-tiodi-p -phenylene bis (phosphorothioate) at $100 \mathrm{ppm}$, equivalent to the concentration used by the National Health Foundation (FUNASA) for the larvicidal control of the vector, in addition to Novaluron ( \pm -1- [3-chloro-4- (1-1-3 -trifluro-2-trifluoromethoxyethoxy) phenyl-3- (2,6-diflurobenzoyl) urea at $0.02 \mathrm{mg} \mathrm{L}^{-1}$, dose adopted by the Ministry of Health, which indicates by the WHO in the range of 0.01 to $0.05 \mathrm{mg} \mathrm{L}^{-1}$.

After $24 \mathrm{~h}$ the counting of alive and dead was performed, being considered dead, the larvae that did not react to the touch after 24 hours of the beginning of the experiment. To quantify the efficiency of the EOs, the statistical test of Probit (Finney, 1952) was applied.

\section{Results and Discussion}

\subsection{Phytochemical screening}

Phytochemical analysis enabled the determination of secondary metabolites present in the analyzed plant materials, shown in Table 1.

Table 1. Phytochemical screening of $P$. amboinicus.

\begin{tabular}{|c|c|c|c|c|c|c|c|c|}
\hline \multirow[b]{2}{*}{ Species } & \multicolumn{8}{|c|}{ Classes } \\
\hline & 1 & 2 & 3 & 4 & 5 & 6 & 7 & 8 \\
\hline amboinicus & + & - & + & + & + & + & + & + \\
\hline
\end{tabular}

Note:1 - Steroids; 2 - Alkaloids; 3-Flavonoids; 4-Glycosides; 5-Cardiac glycosides; 6-Saponins; 7-Phenols; 8-Tannins. Source: Authors (2021).

Table 1 shows the presence of several classes in all analyzed plant materials. The presence of phytochemicals is largely influenced by several factors, including variety, genetic factors, maturation stage, climatic and edaphic 
conditions.According to Menezes Filho and Castro (2019), temperature, water availability, ultraviolet radiation, addition of nutrients, environmental pollution and attack of pathogens are factors that can influence the amount of secondary metabolites present in plant extracts.According to Alfaia (2016), the natural function of many secondary metabolites has been investigated with greater tenacity, being recognized that these are essential for the existence of plants and in several biotechnological applications.

\subsection{Chemical constituents}

According to Table 2, the substances identified in GC / MS, it is possible to highlight that Carvacrol is the major component (69.93\%), followed by Cyclohexanone (11.07\%) and Caryophyllene (5.64\%).

These results are in agreement with the study by (Monzote et al., 2020), who also found a high percentage in the aerial parts of $P$. amboinicus with a $71 \%$ content of carvacrol. The chemical composition of the essential oil of P. amboinicus is influenced by the extraction methodology and the seasonality of the plant (de Freitas Bezerra et al., 2017).

De Freitas Bezerra et al., (2017) observed that the extraction of mint leaves by hydrodistillation showed better results, when compared to steam distillation. The content of carvacrol reached $68 \%$ in the period of October 2014, being the major component and the Caryophyllene was quantified with $8.1 \%$ in the same period, presenting results similar to this study.

Table 2. Chemical constituents identified in the essential oil of $P$. amboinicus

\begin{tabular}{cccc}
\hline ID & RT $($ min) & Content\% & Compounds \\
\hline $\mathbf{1}$ & 15,016 & $\mathbf{0 . 9 8}$ & Terpinen-4-ol \\
$\mathbf{2}$ & 16,626 & $\mathbf{0 . 8 6}$ & Tymol \\
$\mathbf{3}$ & 16,788 & $\mathbf{6 9 . 9 3}$ & Carvacrol \\
$\mathbf{4}$ & 17,383 & $\mathbf{0 . 9 0}$ & Piperitenone \\
$\mathbf{5}$ & 17,676 & $\mathbf{1 1 . 0 7}$ & Cyclohexanone \\
$\mathbf{6}$ & 18,528 & $\mathbf{5 . 6 4}$ & Caryophyllene \\
$\mathbf{7}$ & 18,645 & $\mathbf{3 . 3 1}$ & Bergamotene \\
$\mathbf{8}$ & 18,999 & $\mathbf{1 . 9 4}$ & $\alpha$-Caryophyllene \\
$\mathbf{9}$ & 19,318 & $\mathbf{0 . 9 4}$ & Germacrene D \\
$\mathbf{1 0}$ & 19,592 & $\mathbf{0 . 7 7}$ & $\beta$-Bisabolene \\
$\mathbf{1 1}$ & 20,595 & $\mathbf{3 . 6 6}$ & Caryophyllene oxide \\
\hline
\end{tabular}

Source: Authors.

However, in a study by Santos et al., (2015), results inferior to this study were quantified in relation to the chemical composition of the leaves of $P$. amboinoicus, with carvacrol being 37.7\%, caryophyllene and cyclohexanone were not quantified. The same was presented by Huang et al., (2019), with a content of carvracol of $61.53 \%$, and the chemical components caryophyllene and cyclohexanone were also not found in this study. These results confirm the presence of a satisfactory percentage of the chemical components observed in the EO of this study.

\subsection{Larvicidal activity in vitro front Aedes aegypti}

Table 3 shows the $\mathrm{LC}_{50}$ and $\mathrm{LC}_{90}$ referring to the action of the $\mathrm{EO}$ against the larvae of Aedes aegypti calculated through the log of the intersection of the curves. 
Table 3. Mortality Aedes aegypti for action of essential oil.

\begin{tabular}{|c|c|c|c|c|c|c|}
\hline $\log C$ & Mortality & $\begin{array}{l}\mathrm{LC}_{50} \\
\mathrm{mg} \mathrm{L}^{-1}\end{array}$ & $\begin{array}{c}\operatorname{LC}_{90} \\
\operatorname{mg~L}^{-1}\end{array}$ & $\chi^{2}$ & $\sigma$ & $\mathbf{R}^{2}$ \\
\hline 1.00 & 19.0 & \multirow{8}{*}{$\begin{array}{c}28.52 \\
(21.39-38.03)\end{array}$} & \multirow{8}{*}{$\begin{array}{c}49.55 \\
(40.31-62.33)\end{array}$} & \multirow{8}{*}{0.997} & \multirow{8}{*}{0.390} & \multirow{8}{*}{0.874} \\
\hline 1.30 & 34.8 & & & & & \\
\hline 1.48 & 47.5 & & & & & \\
\hline 1.70 & 50.7 & & & & & \\
\hline 1.78 & 69.7 & & & & & \\
\hline 1.85 & 88.7 & & & & & \\
\hline 1.95 & 95.0 & & & & & \\
\hline 2.00 & 95.0 & & & & & \\
\hline
\end{tabular}

Source: Authors.

Regarding the larval activity of $P$. amboinicus EO, it is possible to observe that through Table 3, the plant presented $\mathrm{LC}_{50}$ of $28.52 \mathrm{mg} \mathrm{L}^{-1}$ and $\mathrm{LC}_{90}$ of $49.55 \mathrm{mg} \mathrm{L}^{-1}$ against the larvae of the mosquito Aedes aegypti.

According to the criteria of Dias and Moraes (2014), essential oils with lethal concentrations ( $\mathrm{LC}_{50}$ ) below $50 \mathrm{mg} \mathrm{L}^{-1}$ are classified as highly active, to be considered active they must have $\mathrm{LC}_{50}$ below $100 \mathrm{mg} \mathrm{L}^{-1}$ and inactive when they have higher $\mathrm{LC}_{50}$ at $100 \mathrm{mg} \mathrm{L}^{-1}$, confirming the larvicidal potential of the $\mathrm{EO}$ assessed in this study.

These results are in agreement with the findings in the literature, which confirm the potential of P. amboinicus EO. Paramasivam et al., (2020) when assessing the larvicidal activity of extracts of P. amboinicus, collected in India, observed maximum activity with minimum concentrations against the larvae of the mosquito of the 4th instar of Aedes aegypti, with $\mathrm{LC}_{50}$ ranging between 53, 36 and $13.64 \mu \mathrm{g} \mathrm{mL}^{-1}$ and $\mathrm{LC}_{90}$ of 92.51 and $86.09 \mu \mathrm{g} \mathrm{mL}^{-1}$.

In a recent study by Huang et al., (2019), they obtained a higher value than this study, with an $\mathrm{LC}_{50}$ of $42.90 \mathrm{mg} \mathrm{L}^{-1}$, in the evaluation of the larvicidal action of the peppermint EO, against the larvae of the mosquito Aedes aegypti. The same was reported by dos Santos et al., (2020) who obtained an $\mathrm{LC}_{50}$ of $41.7 \mathrm{mg} \mathrm{L}^{-1}$ for the larvicidal activity of $P$. amboinicus EO, however, they are classified as highly active, as in this study.

In a study by Jayaraman, Senthilkumar and Venkatesalu (2015), they observed that after 12h, the larvicidal potential of the methanol extract of $P$. amboinicus against Aedes aegypti larvae was $322.67 \mathrm{ppm}\left(\mathrm{LC}_{50}\right)$ and $601.93 \mathrm{ppm}\left(\mathrm{LC}_{90}\right)$, showing a lower action when purchased at this time. study.

The use of $P$. amboinoicus in traditional medicine, in other words, its biological action is related to the presence of some chemical components, such as carvracol, thymol, phenols and aromatic acids, being very common its application as suddenly natural, as it has a high content of EO on its leaves ( Huang et al., 2019).

\section{Conclusion}

These findings encourage the application of the EO of P. amboinicus in this study as larvicide, as it presents in greater quantity one of the chemical substances (carvracol), which may be associated with its satisfactory biological action, thus allowing the development of an insecticide without effects collateral. 


\section{References}

Alfaia, D. P. S. (2016). Phytochemical evaluation, cytotoxic and antimicrobial analysis of the crude ethanolic extract of the leaves of Annona muricata L. (Annonaceae). Amazon Biota (Biote Amazonie, Biota Amazonia, Amazonian Biota), 6 (1), 26-30.

Alitonou, G. A., Noudogbessi, J. P., Sessou, P., Tonouhewa, A., Avlessi, F., Menut, C., \& Sohounhloue, D. C. (2012). Chemical composition and biological activities of essential oils of Pimenta racemosa (Mill.) JW Moore. from Benin. Int J Biosci, 2(9), 1-12.

Bhatt, S., Gething, P. W., Brady, O. J., Messina, J. P., Farlow, A. W., Moyes, C. L., \& Myers, M. F. (2013). The global distribution and burden of dengue. Nature, 496(7446), 504-507.

Bermúdez, A., Oliveira-Miranda, M. A., \& Velázquez, D. (2005). La investigación etnobotánica sobre plantas medicinales: una revisión de sus objetivos y enfoques actuales. Interciencia, 30(8), 453-459.

Brasil (2019). Boletim Epidemiologico: Monitoramento dos casos de arboviroses urbanas transmitidas pelo Aedes (dengue, chikungunya e Zika) até a Semana Epidemiológica 12 de 2019 e Levantamento Rápido de Índices para Aedes aegypti (LIRAa). Secretaria de Vigilância em Saúde :Ministério da Saúde.

Carvalho, M. D. S. L. D., Caldas, E. D., Degallier, N., Vilarinhos, P. D. T. R., Souza, L. C. K. R. D., Yoshizawa, M. A. C., \& Oliveira, C. D. (2004). Suscetibilidade de larvas de Aedes aegypti ao inseticida temefós no Distrito Federal. Revista de Saúde Pública, 38, 623-629.

Crivelenti, L. Z., Guilherme, L. C., Morelli, S., \& Borin, S. (2010). Toxicidade do inseticida Organofosforado Abate ${ }^{\circ}$ em alevinos de Poecilia reticulata. Embrapa Meio-Norte-Artigo em periódico indexado (ALICE).

De Freitas Bezerra, R. D. C., de Oliveira Neto, F. B., da Silva, F. F. M., Bertini, L. M., \& Alves, L. A. (2017). Seasonal effect in essential oil composition and antioxidant activity of Plectranthus amboinicus leaves. Bioscience Journal, 33(6).

De Souza Duarte, L., Pereira, M. T. M., Pascoal, V. D. Á. B., \& Pascoal, A. C. R. F. (2020). Gênero Campomanesia - uma revisão da literatura de metabólitos secundários não voláteis, fitoquímica, uso popular, atividades biológicas e toxicologia. Eclética Química Journal, 45 (2), $12-22$.

Dias, C. N., \& Moraes, D. F. C. (2014). Essential oils and their compounds as Aedes aegypti L. (Diptera: Culicidae) larvicides. Parasitology research, 113(2), $565-592$.

Dos Santos, A. B. D. S., Everton, G. O., Júnior, R. G. D. O. C., Rosa, P. V. S., Pereira, A. P. M., dos Santos Souza, L., \& Mouchrek Filho, V. E. (2020). Óleos essenciais de Cinnamomum zeylanicum Blume e Plectranthus amboinicus (lour.) Spreng como agentes larvicidas frente as larvas do Aedes aegypti. Brazilian Journal of Development, 6(4), 22355-22369.

Finney, D. J. (1952). Probit analysis: a statistical treatment of the sigmoid response curve. Cambridge university press, Cambridge.

Forattini, O. P. (1962). Entomologia medica vol. I Faculdade de Higiene e Saude Publica.

Gomes, P. R. B., Oliveira, M. B., de Sousa, D. A., da Silva, J. C., Fernandes, R. P., Louzeiro, H. C., \& Fontenele, M. A. (2019). Larvicidal activity, molluscicide and toxicity of the essential oil of Citrus limon peels against, respectively, Aedes aegypti, Biomphalaria glabrata and Artemia salina. Eclética Química Journal, 44(4), 85-95.

Huang, H. T., Lin, C. C., Kuo, T. C., Chen, S. J., \& Huang, R. N. (2019). Phytochemical composition and larvicidal activity of essential oils from herbal plants. Planta, 250(1), 59-68.

Jayaraman, M., Senthilkumar, A., \& Venkatesalu, V. (2015). Evaluation of some aromatic plant extracts for mosquito larvicidal potential against Culex quinquefasciatus, Aedes aegypti, and Anopheles stephensi. Parasitology research, 114(4), 1511-1518.

Kim, E., Oh, C. S., Koh, S. H., Kim, H. S., Kang, K. S., Park, P. S., \& Park, I. K. (2016). Antifungal activities after vaporization of ajowan (Trachyspermum ammi) and allspice (Pimenta dioica) essential oils and blends of their constituents against three Aspergillus species. Journal of EssEntial oil rEsEarch, 28(3), 252-259.

Matos, F. J. A. (2009). Introdução à Fitoquímica Experimental, (3a. ed.) UFC.

Menezes Filho, A. C. P., \& Souza Castro, C. F. (2019). Phytochemical classes of secondary metabolites in foliar ethanolic extracts of species of the brazilian cerrado. Revista Saúde \& Ciência Online, 8 (1), 45-61.

Minott, D. A., \& Brown, H. A. (2007). Differentiation of fruiting and non-fruiting Pimenta dioica (L.) Merr. trees based on composition of leaf volatiles. Journal of Essential Oil Research, 19(4), 354-357.

Mirzahosseini, S. M., Noori, S. A. S., Amanzadeh, Y., Javid, M. G., \& Howyzeh, M. S. (2017). Phytochemical assessment of some native ajowan (Therachyspermum ammi L.) ecotypes in Iran. Industrial crops and products, 105, 142-147.

Monzote, L., Scherbakov, AM, Scull, R., Gutiérrez, YI, Satyal, P., Cos, P., \& Setzer, WN (2020). Avaliação farmacológica do óleo essencial do quimiotipo carvacrol de Plectranthus amboinicus em cultivo em Cuba. Natural Product Communications, 15 (10), $1934578 X 20962233$.

Paramasivam, D., Balasubramanian, B., Park, S., Alagappan, P., Kaul, T., Liu, W., \& Pachiappan, P. (2020). Phytochemical profiling and biologic al activity of Plectranthus amboinicus (Lour.) mediated by various solvent extracts against Aedes aegypti larvae and toxicity evaluation. Asian Pacific Journal of Tropical Medicine, 13(11), 494.

Prophiro, J. S., Silva, O. S., Luna, J. E. D., Piccoli, C. F., Kanis, L. A., \& Silva, M. A. N. da. (2011). Aedes aegypti and Aedes albopictus (Diptera: Culicidae): coexistence and susceptibility to temephos, in municipalities with occurrence of dengue and differentiated characteristics of urbanization. Revista da Sociedade Brasileira de Medicina Tropical, 44(3), 300-305. 
Research, Society and Development, v. 10, n. 4, e15410413846, 2021

(CC BY 4.0) | ISSN 2525-3409 | DOI: http://dx.doi.org/10.33448/rsd-v10i4.13846

Santos, N. O. D., Mariane, B., Lago, J. H. G., Sartorelli, P., Rosa, W., Soares, M. G., ... \& Pascon, R. C. (2015). Assessing the chemical composition and antimicrobial activity of essential oils from Brazilian plants-Eremanthus erythropappus (Asteraceae), Plectrantuns barbatus, and P. amboinicus (Lamiaceae). Molecules, 20(5), 8440-8452.

Silva, H. H. G. D., Silva, I. G. D., Elias, C. N., Lemos, S. P. S., \& Rocha, A. P. (1995). Idade fisiológica dos ovos de aedes (stegomyia) aegypti (Linnaeus, 1762)(diptera, culicidae).

Silva, W. J. D. (2006). Atividade larvicida do óleo essencial de plantas existentes no estado de Sergipe contra Aedes aegy pti Linn. 